\title{
PASAR DAN PEMASARAN
}

Makalah Ini Disusun untuk Memenuhi Tugas Makalah pada Mata Kuliah Kewirausahaan

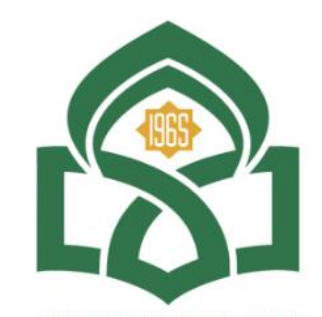

ALAUDDDIN

OLEH:

NIRWANA

90500120065

nirwaaana@gmail.com

PERBANKAN SYARIAH

FAKULTAS EKONOMI DAN FAKULTAS

UNIVERSITAS ISLAM NEGERI ALAUDDIN MAKASSAR

2021 


\section{KATA PENGANTAR}

Puji syukur kami panjatkan kepada Allah SWT. Yang telah memberikan rahmat dan hidayah-Nya sehingga kami dapat menyelesaikan makalah yang kami beri judul "PASAR DAN PEMASARAN"'ini tepat pada waktunya.Adapun tujuan dari penulisan dari makalah ini adalah untuk memenuhi tugas dari bapak dosen pada mata kuliah Kewirausahaan. Selain itu, makalah ini juga bertujuan untuk menambah wawasan tentang Pasar dan pemasaran para pembaca dan juga penulis.Kami mengucapkan terima kasih kepada: Dra. Nuraeni Gani, MM., selaku dosen mata kuliah Kewirausahaan yang telah memberikan tugas ini sehingga dapat menambah pengetahuan dan wawasan sesuai dengan mata kuliah yang kami tekuni.Kami juga mengucapkan terima kasih kepada semua pihak yang telah membantu kami dalam penyelesaian makalah ini.Kami menyadari, makalah yang kami tulis ini masih jauh dari kata sempurna. Oleh karena itu, kami sangat menantikan kritik dan saran yang dapat membangun kesempurnaan makalah ini.

28 November 2021

penulis 


\section{DAFTAR ISI}

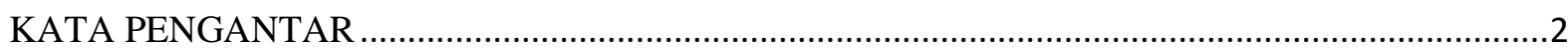

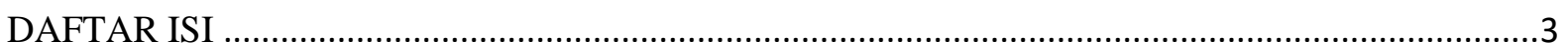

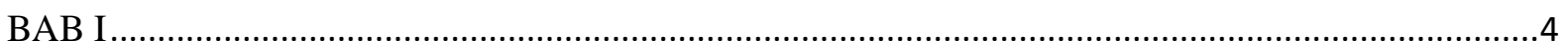

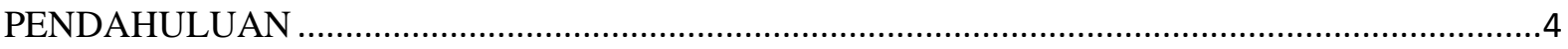

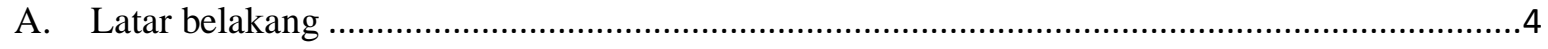

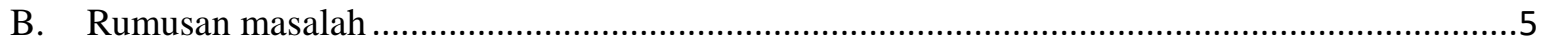

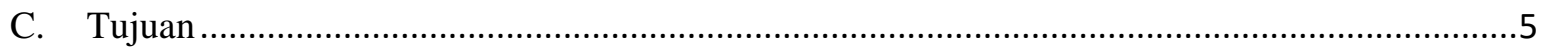

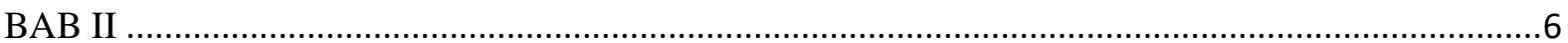

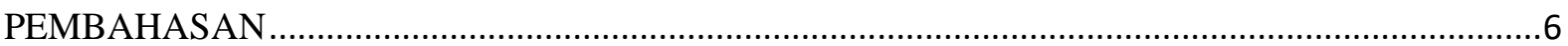

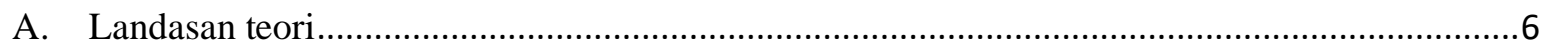

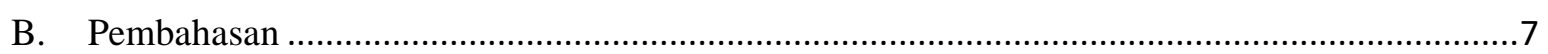

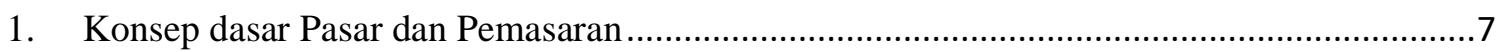

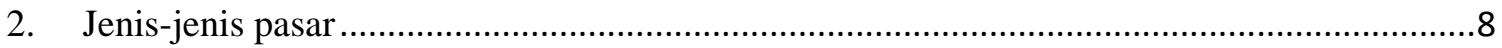

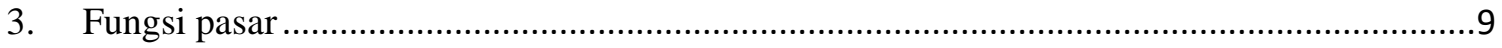

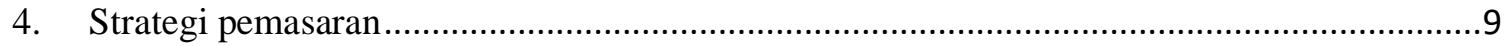

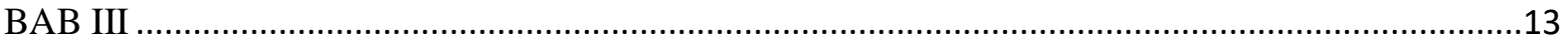

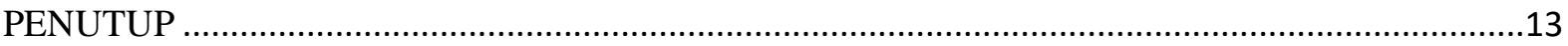

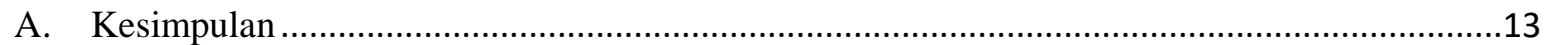

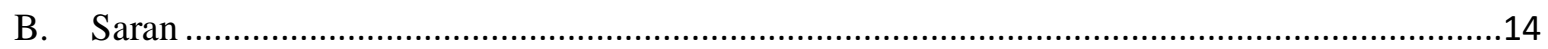

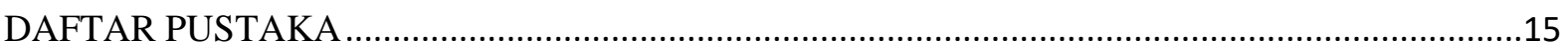




\section{BAB I}

\section{PENDAHULUAN}

\section{A. Latar belakang}

Dalam Keputusan Presiden No. 112 tahun 2007 tentang Penataan dan Pembinaan Pasar Tradisional, pusat perbelanjaan dan toko modern serta Keputusan Menteri Perdagangan Nomor. 53 tahun 2008 sebagai peraturan pelaksanaan Keputusan Presiden, harus mampu membenahi pasar tradisional itu sendiri agar dapat tumbuh dan berkembang ditengah makin berkembangnya suatu usaha eceran berskala besar.Pasar tradisional merupakan salah satu fasilitas umum yang keberadaannya sangat penting dan dibutuhkn oleh masyarkat, khususnya untuk memenuhi salah satu kebutuhan pokok manusia yaitu dalam hal pangan.Namun pasar tradisional identik dengan tempat yang kotor dan beraroma tidak sedap yang disebkan oleh sampah yang bertebaran dimana-mana. Pasar merdeka masih dapat dikategorikan sebagai pasar yang kurang terjaga kebersihan dan kerapiannya, karena di pasar tersebut masih terdapat sampah yang berserakan pada waktu pasar sedang ramai pengunjung. Sarana dan prasarana yang ada pasar Merdeka masih kurang memadai untuk menjadi penunjang kebersihan pasar, faktor inilah yang menjadi salah satu penyebab minimnya kebersihan di pasar Merdeka. Serta ditambah dengan faktor kurangnya kesadaran para pedagang dan pengunjung dalam membuang sampah pada tempatnya menyebabkan meningkatnya jumlah sampah yang berserakan di dalam pasar Merdeka.Untuk menciptakan kenyamanan, kebersihan dan keindahan di pasar dibutuhkan suatu sistem pengelolaan sampah yang efektif dan efisien agar mampu mencapai hasil yang maksimal seperti yang diharapkan. Namun hanya dengan mewujudkan suatu sistem yang baik belum cukup untuk mencapai hasil yang diharapkan, tetapi peran aktif dari pengelola kebersihan serta kesadaran dari para pedagang, pengunjung dan penduduk di sekitar pasar untuk menjaga kebersihan khususnya di lingkungan pasar sangat dibutuhkan. 


\section{B. Rumusan masalah}

1. Apa konsep dasar pasar dan pemasaran?

2. ApaJenis-jenis pasar?

3. Apa saja fungsi pasar?

4. Bagaimana strategi pemasaran?

\section{Tujuan}

1. Untuk mengetahui konsep dasar pasar dan pemasaran

2. Mengetahui jenis-jenis.pasar

3. Untuk mengetahui fungsi pasar

4. Supaya mengetahui strategi pemasaran 


\section{BAB II}

\section{PEMBAHASAN}

\section{A. Landasan teori}

Pemasaran pada praktiknya sudah ada sejak zaman peradaban kuno.[3] Bangsa Yunani Kuno dan Romawi telah mempraktikan ilmu dagang dan secara aktif berkomunikasi persuasif kepada konsumennya.Begitu pula di peradaban-peradaban lain yang maju perdagangannya.Namun, konsep pemasaran modern yang dikenal saat ini baru muncul dan berkembang pada masa Revolusi Industri yang terjadi pada abad ke-18 dan ke-19.Periode ini ditandai dengan munculnya perubahan-perubahan sosial yang didorong oleh perkembangan teknologi dan inovasi ilmu pengetahuan. Salah satu perubahan tersebut adalah munculnya industri-industri yang memproduksi barang konsumsi secara massa.Hal ini didukung pula oleh perkembangan moda transportasi dan munculnya media massa yang mengharuskan produsen menemukan cara mengelola distribusi barang dan jasa.

Pada masa Revolusi Industri, barang-barang konsumsi masih tergolong langka dan produsen bisa menjual hampir semua barang yang mereka produksi selama konsumen mampu membelinya.Karena itu, mereka fokus ke arah pengembangan produksi dan distribusi dengan berusaha menekan biaya sekecil-kecilnya.Ini juga berpengaruh terhadap perkembangan ilmu pemasaran kala itu, yang terkonsentrasi pada efisiensi biaya distribusi dan pembukaan pasar baru. 


\section{B. Pembahasan}

\section{Konsep dasar Pasar dan Pemasaran}

pasar dalam arti sempit adalah suatu tempat dimana pada hari tertentu para penjual dan pembeli dapat bertemu untuk jual beli barang. Sedangkan pengertian pasar dipakai dalam arti yang lebih luas yaitu dimana pertemuan antara penjual dan pembeli untuk melaksanakan transaksi jual beli tidak lagi terbatas pada suatu tempat tertentu saja maupun pada hari tertentu. Pendapat lain dikemukakan oleh Miller dan Meiners, yang mengatakan pasar dalam arti luas adalah suatu pasar tidaklah harus suatu tempat, tapi suatu institusi yang menjadi ajang operasi kekuatan-kekuatan yang menentukan harga, dengan kata lain dalam pasarlah pemasokan dan permintaan beroperasi.Sedangkan pengertian pasar menurut Dahl dan Hammond mengatakan bahwa "pasar adalah sebagai suatu lingkungan atau ruang tempat kekuatan permintaan dan penawaran bekerja untuk menentukan atau memodifikasi harga sehinggga terjadi pertukaran kepemilikan barang dan jasa serta adanya fakta kegiatan fisik dan institusional" (Marketissome, sphere, orspace, (1) where the force of demand an dsupply are atwork, (2) todetermine, ormodify, price, (3) as the owner ship of some quantity of good or service, istrans ferred, and (4) certain physicalan dinstitution alarrang ement smay beev idence).

Pemasaran (bahasa Inggris: marketing) adalah aktivitas dan proses menciptakan, mengomunikasikan, menyampaikan, dan mempertukarkan tawaran yang bernilai bagi pelanggan, klien, mitra, dan masyarakat umum.Pemasaran dimulai dengan pemenuhan kebutuhan manusia yang kemudian bertumbuh menjadi keinginan manusia. Contohnya, seorang manusia membutuhkan air dalam memenuhi kebutuhan dahaganya. Jika ada segelas air maka kebutuhan dahaganya akan terpenuhi. Namun manusia tidak hanya ingin memenuhi kebutuhannya namun juga ingin memenuhi keinginannya yaitu misalnya segelas air merek Aqua yang bersih dan mudah dibawa. Maka manusia ini memilih 
Aqua botol yang sesuai dengan kebutuhan dalam dahaga dan sesuai dengan keinginannya yang juga mudah dibawa.Proses dalam pemenuhan kebutuhan dan keinginan manusia inilah yang menjadi konsep pemasaran. Mulai dari pemenuhan produk, penetapan harga, pengiriman barang, dan mempromosikan barang. Seseorang yang bekerja dibidang pemasaran disebut pemasar. Pemasar ini sebaiknya memiliki pengetahuan dalam konsep dan prinsip pemasaran agar kegiatan pemasaran dapat tercapai sesuai dengan kebutuhan dan keinginan manusia terutama pihak konsumen yang dituju.

\section{Jenis-jenis pasar}

Menurut Mentri Perindustrian RI dalam Keputusan Mentri Perindustrian dan Perdagangan Republik Indonesia Nomor 23/MPP/KEP/1/1998 tentang Lembagalembaga usaha perdagangan :

a) Pasar didasarkan pada kelas mutu pelayanan dan menurut sifat pendistribusiannya adalah

- Pasar Modern, adalah pasar yang dibangun oleh Pemerintah, Swasta, atau Koperasi yang dalam bentuknya berupa Mall, Supermarket, Department Store, dan Shopping Centre dimana pengelolaannya dilaksanakan secara modern, dan mengutamakan pelayanan kenyamanan berbelanja dengan manajemen berada disatu tangan, bermodal relatif kuat, dan dilengkapi label harga yang pasti.

- Pasar Tradisional, adalah pasar yang dibangun dan dikelola oleh Pemerintah, Swasta, Koperasi atau Swadaya Masyarakat dengan tempat usaha berupa toko, kios, los dan tenda, yang dimiliki/dikelola oleh Pedagang Kecil dan Menengah, dan Koperasi, dengan usaha skala kecil dan modal kecil, dan dengan proses jual beli melalui tawar-menawar 
- Pasar Grosir, adalah pasar tempat dilakukannya usaha perdagangan partai besar.

- Pasar Eceran, adalah pasar tempat dilakukannya usaha perdagangan dalam partai kecil.

- Pasar Swalayan (Super Market), adalah pasar yang kegiatan usahanya menjual barang-barang kebutuhan sehari-hari secara langsung kepada konsumen dengan teknik pelayanan oleh konsumen itu sendiri.

b) pasar digolongkan menurut skala luas wilayaahnya yaitu :

- Skala kurang dari 8000 m2 disebut pasar kecil.

- Skala $8000 \mathrm{~m} 2$ - $10.000 \mathrm{~m} 2$ disebut pasar sedang.

- Skala lebih dari $10.000 \mathrm{~m} 2$

\section{Fungsi pasar}

Selanjutnya menurut Miller dan Meiners mengatakan bahwa pasar memiliki dua fungsi yang sangat penting yaitu :

a) Pasar kompetitif menyediakan informasi atau pengetahuan yang harus dimiliki oleh konsumen dan produsen dalam rangka memperhitungkan peningkatan penurunan barang-barang langka atau sumber daya produktif melalui penyesuaian harga relatif yang mudah dipahami.

b) Pasar berfungsi memotivasi konsumen dan produsen untuk bereaksi atau memberi tanggapan secara layak informasi. Dengan memberi imbalan yang lebih tinggi baik itu berupa upah, laba, atau utilitas kepada produsen dan

\section{Strategi pemasaran}

Strategi pemasaran merupakan hal yang sangat penting bagi perusahaan di mana strategi pemasaran merupakan suatu cara mencapai tujuan dari sebuah perusahaan, karena potensi untuk menjual proposisi terbatas pada jumlah orang yang mengetahui hal 
tersebut. Hal ini juga didukung oleh pendapat Swastha "Strategi adalah serangkaian rancangan besar yang menggambarkan bagaimana sebuah perusahaan harus beroperasi untuk mencapai tujuannya."Sehingga dalam menjalankan usaha kecil khususnya diperlukan adanya pengembangan melalui strategi pemasarannya. Karena pada saat kondisi kritis justru usaha kecillah yang mampu memberikan pertumbuhan terhadap pendapatan masyarakat. Pemasaran menurut W. Y. Stanton Pemasaran ialah sesuatu yang mencakup seluruh sistem yang bersangkutan dengan destinasi untuk merencanakan dan menilai harga hingga dengan mempromosikan dan menyalurkan barang dan jasa yang dapat memuaskan keperluan pembeli aktual maupun potensial

Berdasarkan definisi di atas, proses pemasaran dimulai dari menemukan apa yang diinginkan oleh konsumen. Yang akhirnya pemasaran memiliki tujuan yaitu:

a) Konsumen potensial mengetahui secara detail produk yang kita hasilkan dan perusahaan dapat menyediakan semua permintaan mereka atas produk yang dihasilkan.

b) Perusahaan dapat menjelaskan secara detail semua kegiatan yang berhubungan dengan pemasaran. Kegiatan pemasaran ini meliputi berbagai kegiatan, mulai dari penjelasan mengenai produk, desain produk, promosi produk, pengiklanan produk, komunikasi kepada konsumen, sampai pengiriman produk agar sampai ke tangan konsumen secara cepat.

c) Mengenal dan memahami konsumen sedemikian rupa sehingga produk cocok dengannya dan dapat terjual dengan sendirinya.

Pada umumnya kegiatan pemasaran berkaitan dengan koordinasi beberapa kegiatan bisnis. Strategi pemasaran ini dipengaruhi oleh faktor-faktor sebagai berikut:

a) Faktor mikro, yaitu perantara pemasaran, pemasok, pesaing dan masyarakat 
b) Faktor makro, yaitu demografi/ekonomi, politik/hukum, teknologi/fisik, dan sosial/budaya.

Berikut ini adalah hal-hal yang perlu diperhatikan untuk pemasaran: Dari sudut pandang penjual:

a) Tempat yang strategis (place),

b) Produk yang bermutu (product),

c) Harga yang kompetitif (price),

d) Promosi yang gencar (promotion),

e) Sumber daya manusia (people),

f) Proses atau aktivitas bisnis (process), dan

g) Bukti fisik perusahaan (pysicalevidence).

Dari sudut pandang konsumen:

a) Kebutuhan dan keinginan konsumen (customerneedsandwants),

b) Biaya konsumen (costtothecustomer),

c) Kenyamanan (convenience), dan

d) Komunikasi (comunication).

Dari apa yang sudah dibahas di atas ada beberapa hal yang dapat disimpulkan, bahwa pembuatan produk atau jasa yang diinginkan oleh konsumen harus menjadi fokus kegiatan operasional maupun perencanaan suatu perusahaan. Pemasaran yang berkesinambungan harus adanya koordinasi yang baik dengan berbagai departemen (tidak hanya di bagian pemasaran saja), sehingga dapat menciptakan sinergi di dalam upaya melakukan kegiatan pemasaran. 


\section{BAB III}

\section{PENUTUP}

\section{A. Kesimpulan}

pasar adalah sebagai suatu lingkungan atau ruang tempat kekuatan permintaan dan penawaran bekerja untuk menentukan atau memodifikasi harga sehinggga terjadi pertukaran kepemilikan barang dan jasa serta adanya fakta kegiatan fisik dan institusional, sedangkan Pemasaran (bahasa Inggris: marketing) adalah aktivitas dan proses menciptakan, mengomunikasikan, menyampaikan, dan mempertukarkan tawaran yang bernilai bagi pelanggan, klien, mitra, dan masyarakat umum.pasara di bedakan menjadi dua jenis Pasar didasarkan pada kelas mutu pelayanan dan menurut sifat pendistribusiannya(Pasar Modern,Pasar Tradisional, Pasar Grosir,PasarEceran,Pasar Swalayan (Super Market) pasar digolongkan menurut skala luas wilayaahnya yaitu (Skala kurang dari $8000 \mathrm{~m} 2$ disebut pasar kecil, Skala 8000 m2 - 10.000 m2disebut pasar sedang,Skala lebih dari 10.000 m2).Adapun fungsi pasar yaitu Pasar kompetitif menyediakan informasi atau pengetahuan yang harus dimiliki oleh konsumen dan produsen dalam rangka memperhitungkan peningkatan penurunan barang-barang langka atau sumber daya produktif melalui penyesuaian harga relatif yang mudah dipaham dan Pasar berfungsimemotivasi konsumen dan produsen untuk bereaksi atau memberi tanggapan secara layak informasi. Dengan memberi imbalan yang lebih tinggi baik itu berupa upah, laba, atau utilitas kepada produsen dan 


\section{B. Saran}

kami harap bagi pembaca bila menemukan kekeliruan atau kata yang mempunyai makna menyinggung ataupun salah dalam penerapan dalam kehidupan pembaca/bertentangan maka kami mohon maaf, karena kami pembuat makalah ini hanya ciptaan yang mungkin masih memilikikekurangan. 


\section{DAFTAR PUSTAKA}

Hariandja, M. T. (2017). Manajemen Sumber Daya Manusia Pengadaan,Perkembangan,dan Peningkatan Produktivitas Pegawai. Jakarta: Pt.Gramedia Widiasarana Indonesia .

Sakban, I. N. (2019). Manajemen Sumber Daya Manusia. jurnal of administration edcational management, 2 (1), 101-102.

Suryani, N. K. (2019). Manajemen Sumber Daya Manusia. Bandung: Nilacakra.

https://www.intipesan.com/sejarah-perkembangan-manajemen-sdm/ 